WSRC-MS-97-0180

CONF-9706124--1

\title{
Russian Studies of the Safety of Anion Exchange In Nitric Acid
}

by

M. L. Hyder

Westinghouse Savannah River Company

Savannah River Site

Aiken, South Carolina 29808

V. N. Romanovskv

V. G. Khlopin Radium Inst.. Russian Federation

S. A. Bartenev

V. G. Khlopin Radium Inst., Russian Federation

L. N. Lazarev

V. G. Khlopin Radium Inst., Russian Federation

S. A. Strelkov

V. G. Khlopin Radium Inst., Russian Federation

E. R. Nazin

N. E. Timochenko Acad. of Chemical Protection

G. M. Zachinvaev

N. E. Timochenko Acad. of Chemical Protection

A. I. Malivch

Chelvabinsk-65, Russian Federation

\section{MASTER}

A document prepared for 21ST ANNUAL ACTINIDE SEPARATIONS CONFERENCE at Charleston, SC, USA from $6 / 23 / 97-6 / 26 / 97$.

DOE Contract No. DE-AC09-96SR18500

This paper was prepared in connection with work done under the above contract number with the U.S.

Department of Energy. By acceptance of this paper, the publisher and/or recipient acknowledges the U.S. Government's right to retain a nonexclusive, royalty-free license in and to any copyright covering this paper, along with the right to reproduce and to authorize others to reproduce all or part of the copyrighted paper. 


\section{DISCLATMER}

This report was prepared as an account of work sponsored by an agency of.the United States Government. Neither the United States Government nor any agency thereof, nor any of their employees, makes any warranty, express or implied, or assumes any legal liability or. -responsibility for the accuracy, completeness, or usefilness of any information, apparatus, product, or process disclosed, or represents that its use would not infringe privately owned rights. Reference herein to any specific commercial product, process, or service by trade name, trademark, manufacturer, or otherwise does not necessarily constitute or imply its eadorsement, recommendation, or favoring by the United States Government ar any agency thereof. The views and opinions of authors expressed herein do not necessarily state or reflect those of the United States Govemment or any agency thereof.

This report has been reproduced directly from the best available copy.

Available to DOE and DOE contractors from the Office of Scientific and Tochnical Information, P.O. Box 62, Oak Ridge, TN 37831; prices available from (615) 57.6-8401.

Available to the public from the.National Technical-Information Service, U.S. Department of Commerce, 5285 Port Royal Road, Springfield, VA 22161. 


\section{DISCLAMMER}

Portions of this document may be illegible in electronic image products. Images are produced from the best available original document. 


\section{Russian Studies of the Safety of Anion Exchange in Nitric Acid}

\section{Introduction}

Synthetic ion exchange resins came into use in the Soviet Union in the 1950 's, and domestic anion exchange resins based on quaternary amine groups have long been used in the Russian nuclear industry. These resins are similar to resins used in the West, and include pyridine-based resins, as well as the more conventional aryl polymers with substituted methyl amines. (Slide 1)

The sensitivity of these amines to reaction with nitric acid and other oxidants has been a concern in Russia as in the West, and numerous laboratory studies have been conducted on the reactions involved. Several incidents involving pressure or temperature excursions have provided incentives for such studies. (Slide 2) This report briefly summarizes this work. A report by the Russian authors of this paper providing greater detail is to be issued as a U. S. Dept. of Energy document. Additionally, a second report by these authors, describing new studies on anion exchange resin safety, will also be issued as a DOE report.

The separation of plutonium, neptunium, etc. from other materials by ion exchange requires rather strong nitric acid (6-8 M). In some systems, such as the processing of $238 \mathrm{Pu}$, intense ionizing radiation may also be present during ion exchange separation. As a result, it is necessary to consider not only thermal hydrolysis and oxidation and their effects on the resin, but also radiolysis. All of these were investigated in the Russian studies.

\section{Thermal Degradation}

Heating can degrade anion resin, particularly in the presence of oxidants. The first part of slide 3 shows the effect of heating the AV- 17 resin in water, in terms of both loss of strong base capacity, and of formation of methanol. Methanol is formed by hydrolysis of the amine, leaving behind a weaker base. The second section of the table shows the effect of heating the pyridinium resin in water under autoclave conditions. This resin is more resistant to hydrolytic damage.

\section{Radiolysis}

Ion exchange resins used for radiochemical separations are generally exposed to ionizing radiation, and alpha radiation in particular. The effect of such irradiation on the resin and its properties has been the subject of extensive investigation throughout the world. Some of the Soviet studies are briefly summarized here. Particular emphasis in these studies has been placed on pyridine-based resins, which tend to be more resistent to radiation than conventional substituted benzenes.

Slide 4 shows the effect of irradiation on capacity for a conventional ion exchange resin, the Russian AV-17 (x6), which is similar in structure to Dowex 1. The irradiation was peformed on resin in water. At a dose of $3 \mathrm{MGy}$ more than $75 \%$ of the capacity had been lost, primarily as the result of the loss of the amine group. 
In comparison, Slide 5 shows the effect of ${ }^{60}$ Co radiation on the pyridinium resin VP-1AP, irradiated in nitric acid solution. The loss of exchange capacity tracks the loss of resin weight, and is much less than the corresponding value for conventional resins. The loss of weight apparently corresponds to loss of fragments of the resin. A study by investigators at the Khlopin Institute followed the weight loss, and characterized the fragments. The rapid increase in weight loss above about $3 \mathrm{MGy}$ appears to be associated with large fragments of the polymer matrix breaking away from that matrix. (Slide 6)

In summarizing the available data it was concluded that:

1. In the absence of oxidizers, radiation tends to cross-link resins, but in the presence of oxidizing materials cross-links are broken and the resin swells.

2. Radiation can introduce new functional groups into resins, such as carboxylic acid groups or (in the presence of nitric acid) nitrated groups.

3. Vinylpyridine anion resins, particularly those based on 2,5-methyl-vinyl pyridine, withstand radiation doses up to 3 to $5 \mathrm{MGy}$ with little damage to functional groups or the resin structure.

\section{Safety Considerations}

Safety concerns in ion exchange are dominated by the release of gases from degraded resins. When caused by accelerating chemical reaction, this can lead to explosive bursting of equipment. It has been shown by explosive tests that under some conditions dry, nitrated resins can even be detonated.

Gas evolution in the VP-1AP resin when heated and contacted with nitric acid is shown in Slide 7. The rate is seen to increase with both temperature and acidity. It is noted that these rates do not represent an explosive hazard in an open system, even to the boiling point in contact with $12 \mathrm{M}$ nitric acid.

The effect of ionizing radiation on thermally induced gas evolution is shown in Slide 8. The slide shows that radiation also increases the rate.

In closed apparatus the attainable temperatures are higher, and the rate of gas evolution increases accordingly. (Slide 9) In combination with radiation effects, quite high evolution rates can be observed. These reactions are also exothermic, so the reaction can self-accelerate.

These findings are pertinent to observed excursions in ion exchange apparatus, including the most recent incident which will now be described.

\section{The 1993 Incident}

The most recent safety-related incident involving ion exchange occurred in the Mayak plant in July of 1993 . A quantity of ${ }^{238} \mathrm{Pu}$ was being purified by anion 
exchange in a remote radiochemical facility. The layout of the apparatus was shown in the slide. (Slide 10) A water-jacketed column, SN-04, was loaded with 374 grams of $238 \mathrm{Pu}$ in approximately nitric acid solution. Impurities were removed by washing with $7.0 \mathrm{M}$ nitric acid. Because there was a delay in preparing the elutriant solution, the column was then left for approximately three hours without further activity. At this time a loud noise was heard, and the column was found to have ruptured explosively. Some of the expelled resin was charred.

Analysis of the incident showed that the radioactive loading exceeded usual levels, and that cooling calculations had not been made for this loading. A leak in one of the valves in the system (\#2728) had resulted in manual control of the process, which allowed the column to be isolated from its relief system. The leak in the valve was compensated by pressurizing the line, but this required the valve \#0443 to be closed. This allowed the column to heat up along its top centerline and dry out. Once a region of the loaded column was dry, exothermic reactions caused additional heating and pressurization of the column leading to the explosion. (Slide 11)

Heat transfer calculations have been made on the rate of heating to boiling and dryout in the column. They agree well with the actual observation. Combination of the heating calculations with the thermal studies showed that large amounts of gases would be generated, producing internal pressures in excess of 33 atmospheres. At this point the rupture of the column would be expected.

The apparatus was rebuilt to incorporate a rupture disk and thermocouples to detect unacceptable heating. A supply tank containing desorbing solution was also added, along with a number of automatic safety systems. 

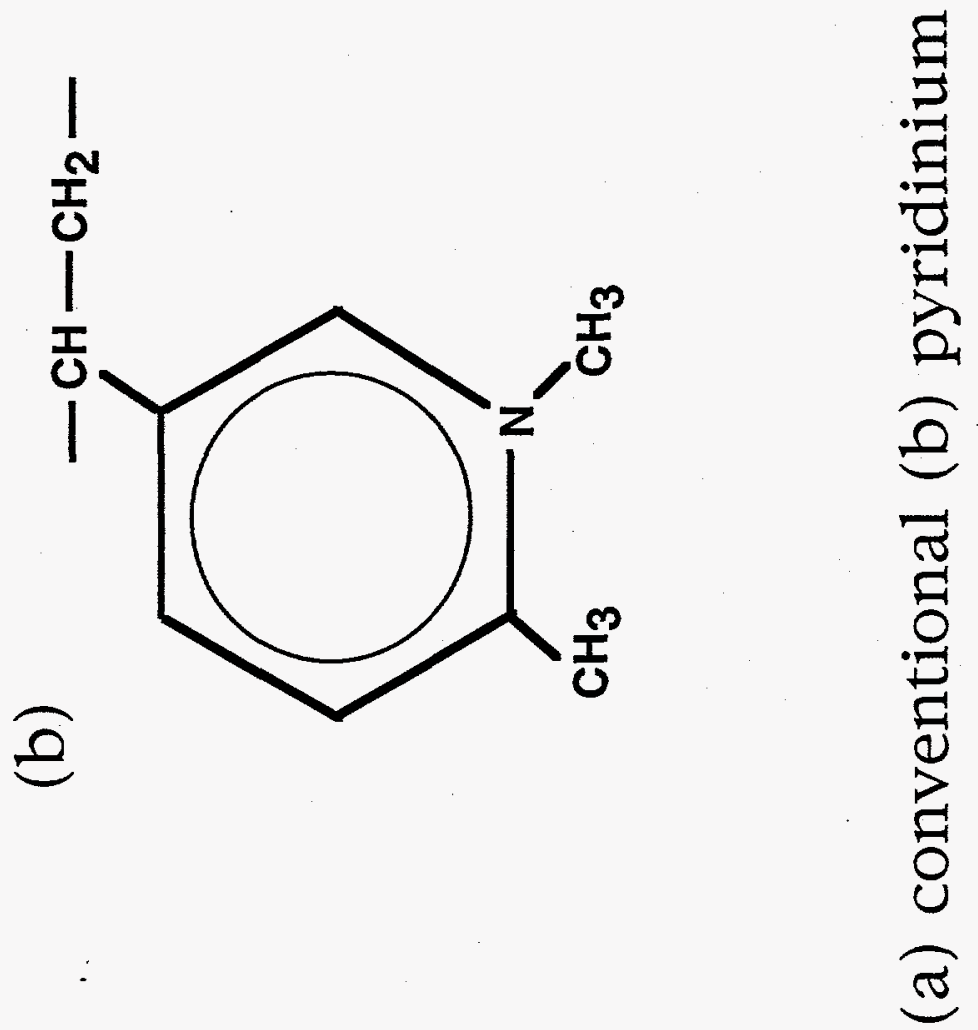

$\frac{\sigma}{\frac{1}{0}}$

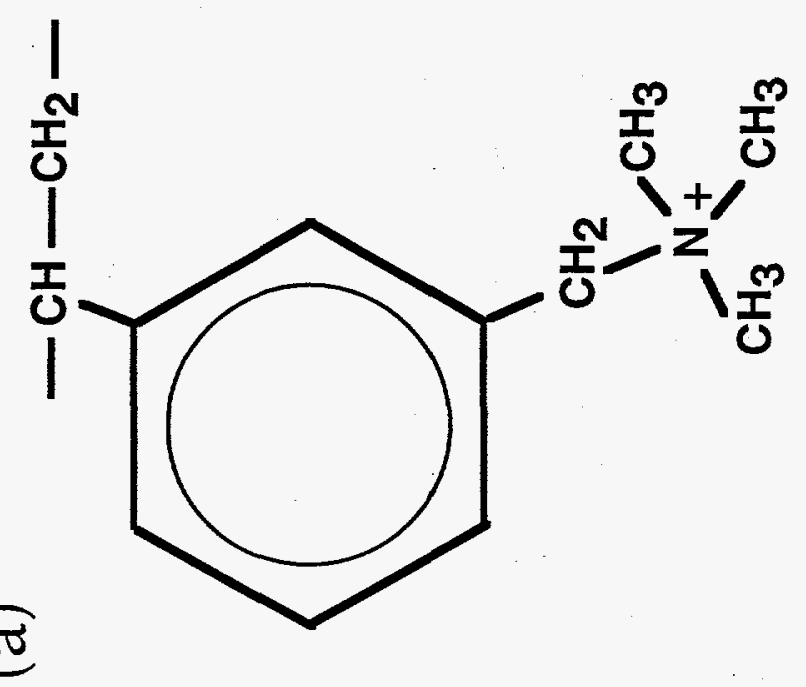

$\stackrel{\dot{s}}{\mathrm{~s}}$

$\pm$

0

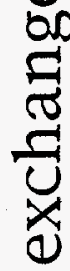

을 


\section{SLIDE 2}

DATE, PLACE INCIDENT $\quad$ CAUSE

$\begin{array}{lll}\text { 2/62, Mayak } & \begin{array}{l}\text { Column Explosion } \\ \text { (Not Loaded) }\end{array} & \begin{array}{l}7 \mathrm{M} \text { Nitric Acid, } 55^{\circ} \text { to } 60^{\circ}, \\ \text { Relief Valve Closed }\end{array} \\ \text { 4/67, Mayak } & \begin{array}{l}\text { Temperature Excursion } \\ \text { (Not Loaded) }\end{array} & \begin{array}{l}\text { Temperature Control Cut Off } \\ 11 / 67, \text { Tomsk-7 }\end{array} \\ \begin{array}{l}\text { Column Explosion } \\ \text { (Not Loaded) }\end{array} & \begin{array}{l}7.5 \mathrm{M} \text { Nitric Acid, plus Hydrogen } \\ \text { Peroxide \& Oxalic Acid. } \\ \text { Relief Valve Closed }\end{array} \\ \text { 12/73, Mayak } & \begin{array}{l}\text { Column Rupture During } \\ \text { 238Pu Processing }\end{array} & \begin{array}{l}\text { Column Heated, Relief Valve } \\ \text { Closed }\end{array} \\ 7 / 93, \text { Mayak } & \begin{array}{l}\text { Column Exploded During } \\ \text { 238Pu Processing }\end{array} & \begin{array}{l}\text { Column Allowed to Stand and } \\ \text { Self-Heat While Isolated } \\ \text { (Inadequate Cooling) }\end{array}\end{array}$


SLIDE 3

\section{Thermal Degradation of Anion Exchange Resins}

AV-17 in Water, $100^{\circ} \mathrm{C}$

Time, Days

Methanol Formed $\mathrm{m} \mathrm{mol} / \mathrm{g}$

Weak Base Formed $\mathrm{meq} / \mathrm{g}$

10

20

30

0.11

0.16

0.31

0.08

0.17

0.29

\section{VP-1AP in Water}

$\mathrm{T},{ }^{\circ} \mathrm{C}$

Heat Time, hr

Capacity, meq/g

230

200

0

36

60

\section{9}

3.8

23. 
SLIDE 4

Effect of Irradiation on Exchange Capacity AV-17 Anion Resin, Crosslinked 6\%, OH- Form 60Co Gamma Radiation

Dose, MGy

$$
\begin{array}{r}
0.0 \\
0.8 \\
1.0 \\
1.6 \\
3.0 \\
6.0 \\
8.0 \\
15.0
\end{array}
$$

Capacity, $\mathrm{mol} / \mathrm{kg}$ resin

4.16

2.76

2.44

1.95

0.91

0.19

0.08

0.02 


\section{SLIDE 5}

Effect of Irradiation of Anion Resin VP-1AP in 7 M Nitric Acid Solution

Dose, MGy

0
2
4
6
10
Weight Loss, \%

$$
\begin{array}{r}
0 \\
3.4 \\
14.8 \\
28.0 \\
35.8
\end{array}
$$

Exchange Capacity, meg/g

3.9

3.6

3.4

3.1

2.5 
SLIDE 6

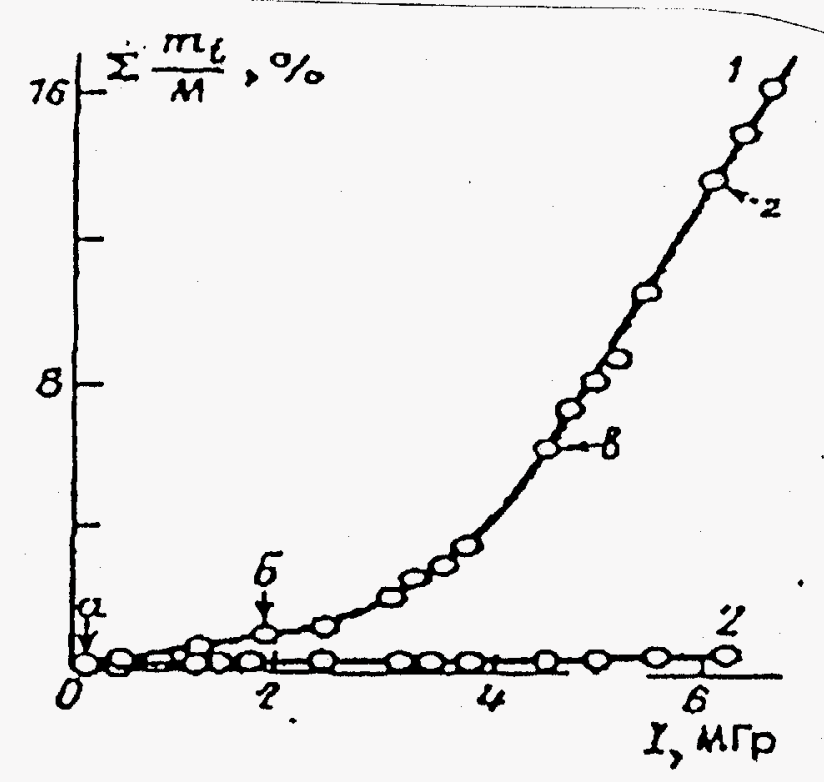

Fig. 2.5. Dependence of total yield of radiolysis products of anionite VP-1AP on absorbed dose [69] M-weight of initial resin, $\sum \mathrm{m}_{1}$ - sum of weights of PR fractions

Curve 1: Irradiated Resin. Curve 2: Unirradiated Blank 
SLIDE 7
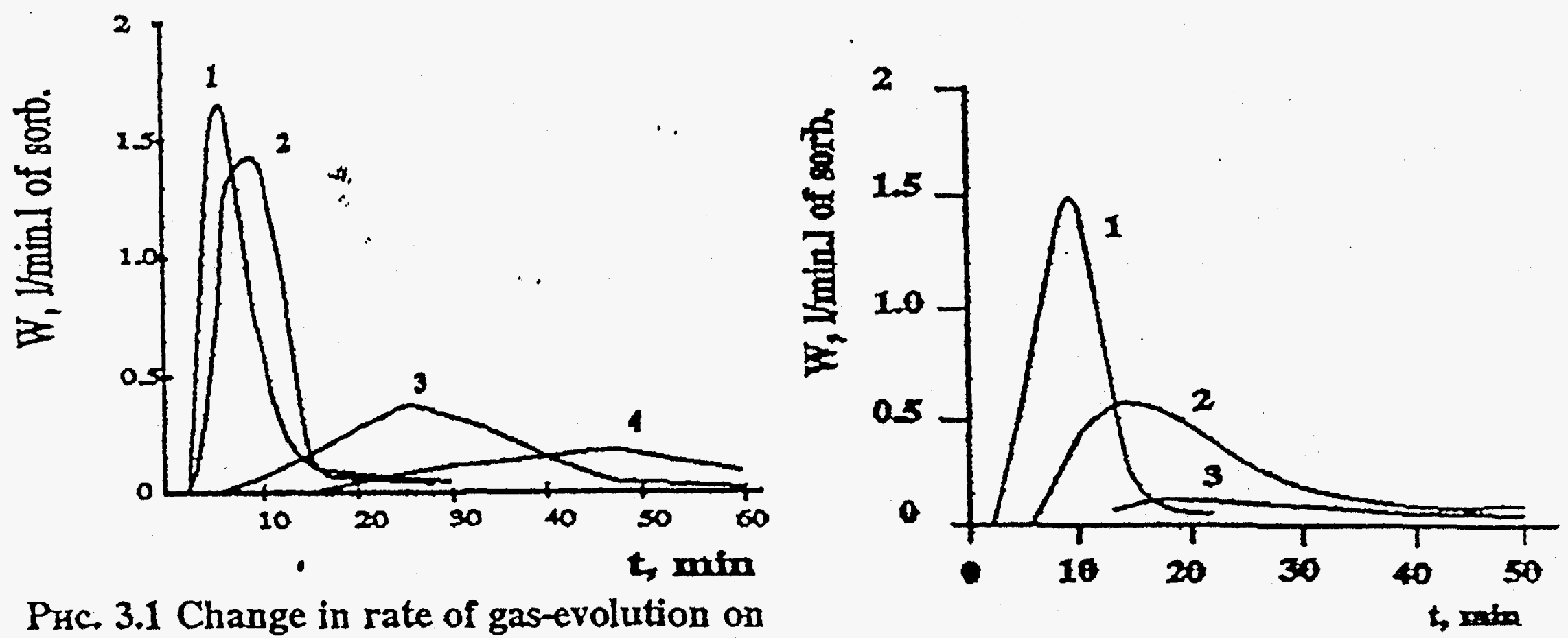

PHc. 3.1 Change in rate of gas-evolution on heat treatment of anionite VP-1AP $\left(\mathrm{SO}_{4}{ }^{2-}\right.$ - $\left.\mathrm{Form}\right)$ in $12 \mathrm{M} \mathrm{HNO}_{3}$ solutions $1-110^{\circ} \mathrm{C}, 2-100{ }^{\circ} \mathrm{C}, 3-90^{\circ} \mathrm{C}, 4-70^{\circ} \mathrm{C}$

Puc. 3.2 Change in rate of gas-evolution on heat treatment of anionite VP-1AP $\left(\mathrm{SO}_{4}{ }^{2-}\right.$-form) in $\mathrm{HNO}_{3}$ solutions 1-12 M, 2- $7 \mathrm{M}, 3-3 \mathrm{M}$. 


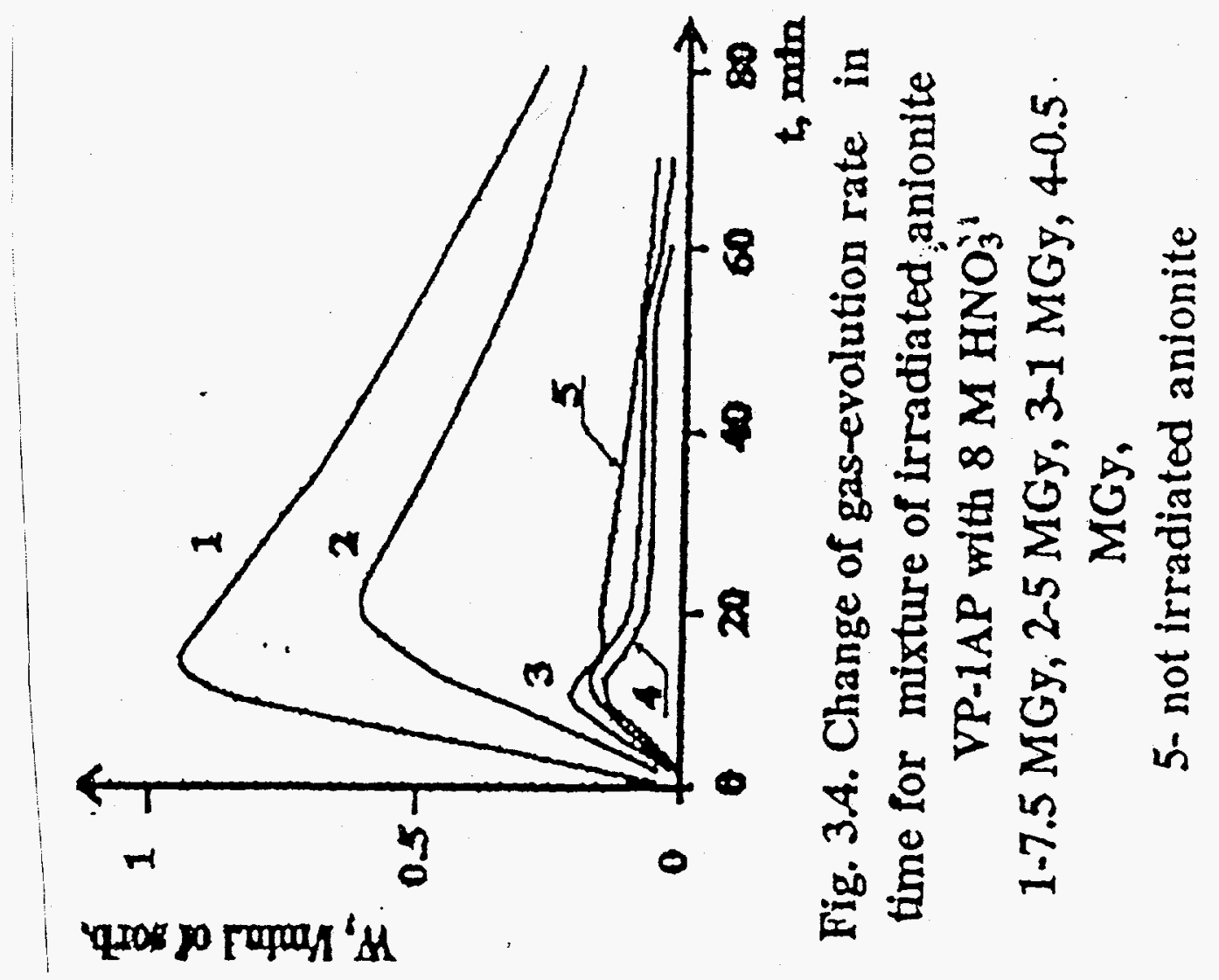

$\infty$
$\frac{11}{0}$ 
SLIDE 9

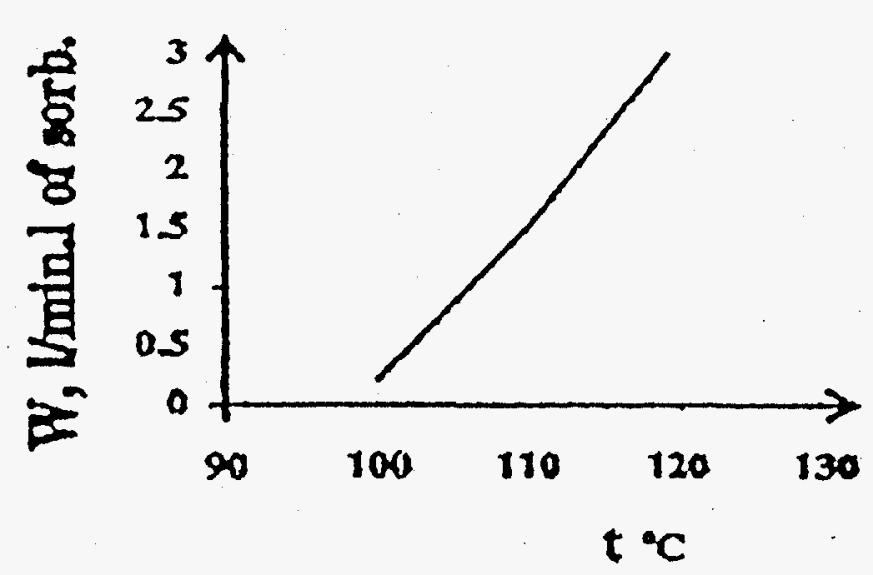

Fig. 3.6 Dependence of the maximum rate of gas-evolution in closed apparatus on temperature of heating 
SLIDE 10

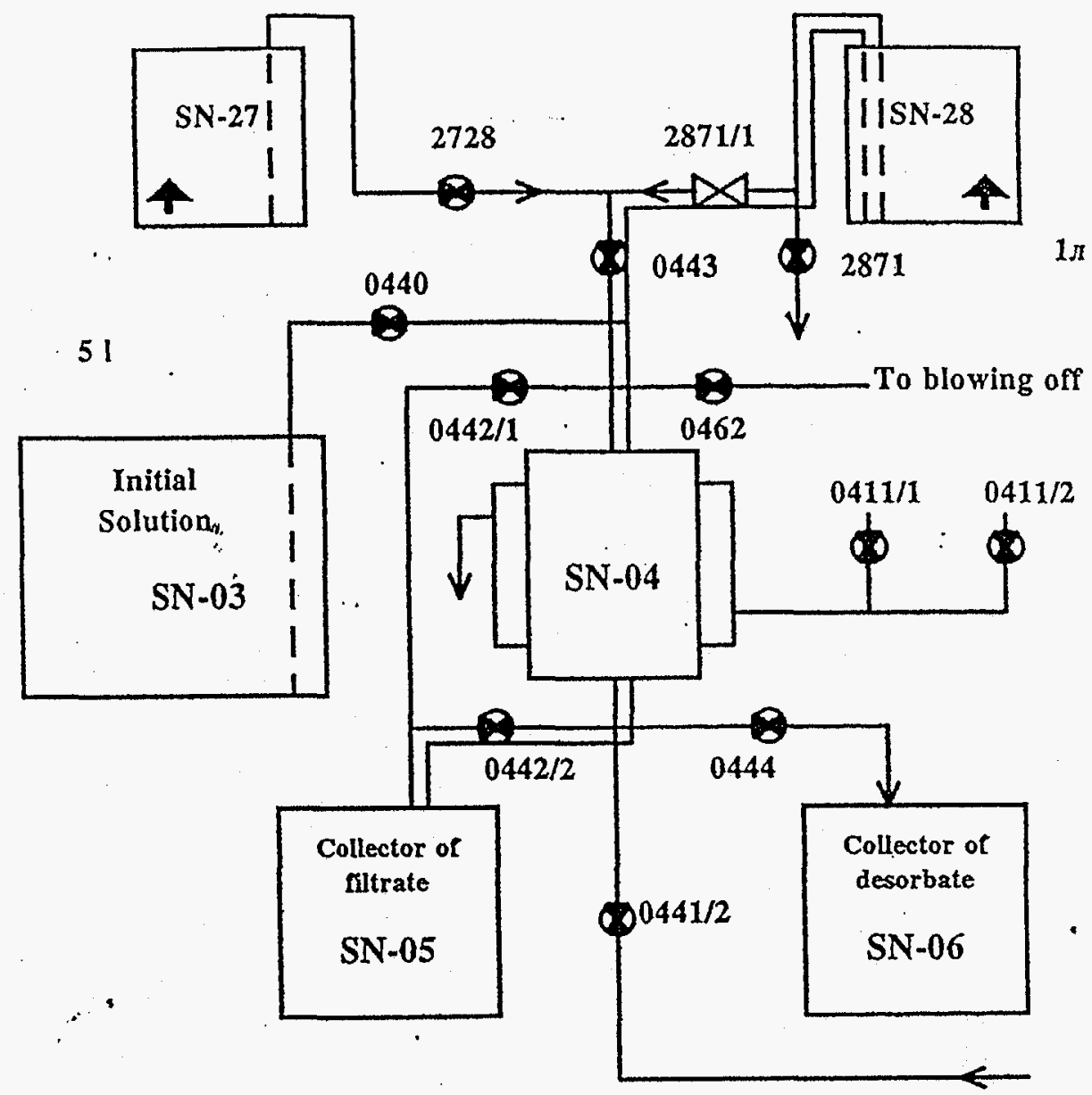

Fig. 4.2. Equipment lay-out for the facility $45-03$

1. Valve 0443 on hand-operated control

2. Residual volume in SN-28 - 11 , delivery rate- $80 \mathrm{l}$ hour

3.Blowing-0fr scheme: SN-28 $\rightarrow$ in $2871 / 1 \rightarrow$ in $0443 \rightarrow$ SN-4 $\rightarrow$ in $0442 / 2 \rightarrow$

(SN-05

4. Time on closing of valve $0442 / 2-1 \mathrm{~min} 15 \mathrm{~s}$

5. Time of closing of hand-operated valves $\sim 4 \div 5 \mathrm{~min}$. 


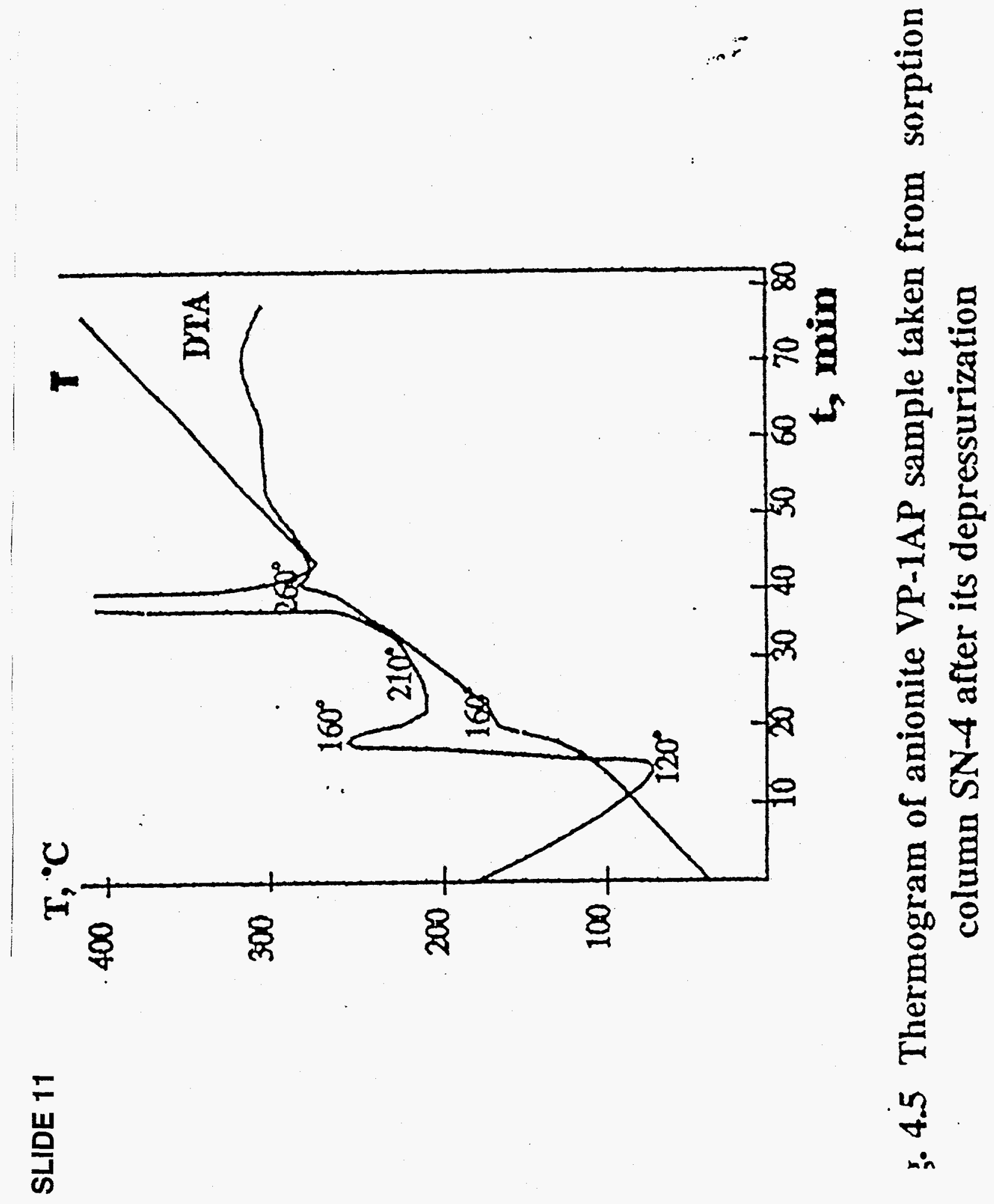

